\section{One of us}

\section{Mark Gould takes a look at the new chief executive of the NHS, David Nicholson}

An almost palpable sigh of relief went up last month as it was announced that David Nicholson, a man who has worked for the NHS for 25 years, is to take over as its new chief executive in September

The appointment from within the service was welcomed by organisations across the public sector-from the BMA to trade unions-as a symbolic act of "protecting" the NHS and its ethos from wholesale privatisation.

Nicholson, a chunky 50 year old with the lived-in look of a retired rugby forward, was the only NHS candidate on the shortlist for what could be considered one of the most daunting jobs in the world. The Department of Health's press release announcing his appointment states that the post now requires management of 1.3 million staff and an annual budget of £90bn (€133bn; \$170bn).

No wonder people were relieved. His rivals for the job included John Rowe, executive chairman of Aetna, one of the largest US health insurers; Ken Kizer, former chief executive of the Veterans Administration, the largest tax funded healthcare provider in the United States; and Ian Smith, chief executive of General Healthcare, Britain's biggest private hospital group.

But there was no time for Nicholson to relax comfortably into his new post, free of criticism. Within days of the announcement, Nicholson was already being marked down in the media as a bad guy.

In a leaked letter from Nicholson dated 27 July-the day his appointment was announced-written in his current role as chief executive of London strategic health authority, he outlines reductions in budget increases for some of the poorest areas of London, to tackle a $£ 70 \mathrm{~m}$ budget shortfall.

And commentators who spoke off the record to the $B M J$ say that Nicholson is not the reincarnation of Nye Bevan. Before his current job, he was previously in charge of Birmingham and the Black Country Strategic Health Authority and stated to one colleague.

Michael Dixon, a Devon GP and chairman of the NHS Alliance, said there was relief that an NHS person had got the job. "He understands the NHS, its principles and ethos, and why that makes it better than many other [systems] and therefore worth holding on to."

Dr Dixon worries at Nicholson's lack of knowledge of primary care, with 25 years in hospitals and senior regional management. However, Nicholson was responsible for the human resources strategy behind Shifting the Balance of Power-the policy document that put primary care in the driving seat in terms of NHS spending decisions.

Dr Dixon feels that Nicholson must win over doctors by his

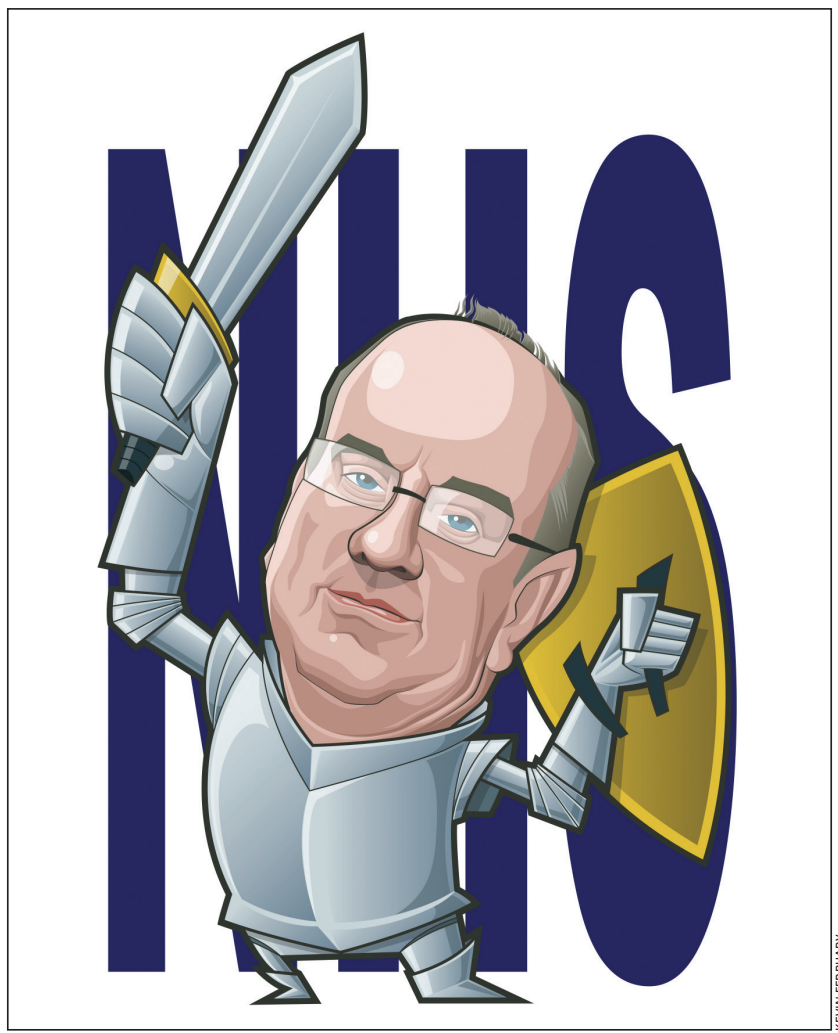

In an interview in June with the Health Service Journal (3 Aug 2006:14), Nicholson emphasised that he wanted to see the government drive reforms faster "right through to the private sector running district general hospitals."

He certainly knows what he wants, according to one source who worked with him in London: "Meetings are a bit of a revelation-you go in, and just get from point $\mathrm{A}$ to point $\mathrm{B}$ with a speed and clarity that can be rare in the upper echelons of the service, and even more rare at Richmond House." actions and by "getting out and talking to us." He added: "The over-riding issue is the question of getting clinicians engaged and being given proper leadership roles in the NHS. That is not happening because management fiefdoms still exist. Proper clinical leadership will mean that payment by results works and will help tackle financial deficits."

When Dr Peter Fisher, the president of the NHS Consultants Association, was asked what Nicholson's key challenges would be, Dr Fisher likened it to the old Irish joke when a lost traveller asks a farmer how to get to town: "Well, you wouldn't want to start from here."

Dr Fisher said the whole notion of patient choice, which in itself was incredibly time consuming, was being undermined by additional tiers of bureaucracy and management interference.

Given his reformist reputation and the leaked letter, it is unlikely Nicholson will heed Dr Fisher's advice that "The NHS needs a rest from new initiatives to allow people to get on with their jobs."

The King's Fund's chief executive, Niall Dickson, thought the appointment a "credit to the NHS," given the contenders from the private sector and the US. "There is no doubt that this is a hugely challenging time for the NHS. Top of David Nicholson's list of priorities will be restoring financial balance to the service and getting to grips with commissioning-the Achilles' heel of the health service," Mr Dickson said.

Nigel Edwards, policy director at the NHS Confederation, says doctors will like Nicholson's "down to earth view of the world." "He's tough but fair minded and will drive quite a hard bargain."

Mr Edwards says Nicholson is pragmatic rather than ideological and is "happy to use the "pick and mix' approach of a plethora of providers."

"He is happy to tell ministers what he thinks," says Mr Edwards. As a chief executive in a strategic health authority, for example, he rejected a Whitehall call to introduce independent treatment centres in the Midlands, saying the NHS was doing fine.

Although one priority for the new NHS chief executive is to get practice based commissioning right, $\mathrm{Mr}$ Edwards wants Nicholson to add stability and a long term strategy to win clinicians' hearts and minds.

"We have seen very much policy being driven by a small group around ministers-of which he was one," he said. "We need an overall strategy, one that doesn't simply say that payment by results [where hospitals are paid on the basis of patients treated] will solve everything."

Although Nicholson's appointment might be taken as a sop to old Labour, Mr Edwards emphasises: "This is a man who has been driving modernisation-he's not going to put the brakes on reform." Mark Gould London 